\title{
MONETARY POLICY AND THE SUSTAINABILITY OF THE MANUFACTURING SECTOR IN NIGERIA
}

\section{Adegbemi Babatunde Onakoya, Grace Oyeyemi Ogundajo, Babatunde Solomon Johnson}

(1) Department of Economics Babcock University, Ilishan - Remo, Nigeria

(2) Department of Accounting Babcock University, Ilishan - Remo, Nigeria

(3) Department of Economics,Babcock University, Ilishan - Remo, Nigeria

Adegbemi Babatunde Onakoya

Department of Economics Babcock University, Ilishan - Remo, Nigeria gbemionakoya@gmail.com

Article info

Paper category: Original Scientific Paper

Received: 31.10.2017.

Accepted: 10.12.2017.

JEL classification: $\mathrm{E}_{52} ; \mathrm{O}_{47} ; \mathrm{P}_{24} ; \mathrm{E}_{4} 3 ; \mathrm{E}_{51} ; \mathrm{F}_{31}$ 


\begin{abstract}
The conflicting results in relationship between monetary policy and the sustainability of the manufacturing sector necessitated this research. The study carried out some preliminary tests including the descriptive statistics and the Augmented Dickey Fuller unit root tests. The optimal lag length criteria, and the Johansen Co-Integration test were applied to verify long run association among the series. The Vector Error Correction model was estimated as a verification of the short run adjustment. The Breusch-Godfrey Serial Correlation Lm test, Durbin Watson Statistic, and Breusch-Pagan Heteroscedasticity tests were conducted. The results confirmed the existence of a long run relationship among the variables. A positive relationship between monetary policy and manufacturing sector performance in Nigeria was observed at the $5 \%$ level of statistical significance. No short run association between the external reserves and inflation rates was recorded. The study therefore recommends that the government avoid monetary policy summersaults.
\end{abstract}

\title{
Keywords:
}

Monetary Policy, Manufacturing output, Inflation, Interest rate, Foreign Exchange rate, 


\section{INTRODUCTION}

Industrialization has been reported as the major driving force serving as the veritable vehicle for goods production, service provision, employment generation and the enhancement of income (Kaldor, 1966, 1967). The manufacturing sector is a leading sector in the Nigerian economy which, in the findings of Onakoya (2015), provides the opportunities for the employment of local human and capital resources, the avenue for import substitution, and the generation of much-needed foreign exchange earning capacity.

The contributions of Nigerian manufacturing into the GDP has been irregular over the years. The sector contributed a paltry $4.8 \%$ to the GDP at the time of independence in 1960. Ku, Mustapha and Goh (2010) report an increase to $7.4 \%$ a decade later largely as a result of foreign direct investments. The highest contribution record of $10.7 \%$ was achieved as of the next decade in 1980 . The growth however, plummeted to $6.3 \%$ in 1985 and continued its downward spiral to $6.3 \%$ in 1997 , and $4.21 \%$ in 2009 (Adenikinju \& Chete, 2002). The result of the re-basing of the GDP of Nigeria to 2010 (hitherto set in 1990) indicated an economy more diversified than had been previously reported. The new contribution of the manufacturing sector to GDP was reported at 6.46\% (in 2011) and 6.83\% (in 2013). As of Quarter 1, 2016. The contribution of manufacturing to Nominal GDP was put at $9.33 \%$ by the National Bureau of Statistics (2016).

Monetary policy is the well-considered procedural efforts of the relevant authority (currency board or central bank) of a country. The objective is usually to achieve price stability and / or a general trust in the currency through the control of the money supply by targeting a desirable interest rate or a rate of inflation. Such policy, as explained by Chigbu and Okonkwo (2014), was usually deployed to influence economic activities. The real objective was to accomplish the desired macroeconomic stability by using the variations in the money supply, the direction of credit, the cost of credit, and the size of credit availability.

The effects of monetary stratagem on the different sectors of the economy do differ. Nwosa, Agbeluyi and Saibu (2011) identified two monetary policy regimes: tight and loose. The deployment of either type depends on the need to achieve prices stability and the maintenance of balance of payment equilibrium. The essence of monetary policy as identified by Onyemu (2012) however, is the achievement of external and internal balance of the value of money in addition to the enhancement of the real sector of the economy, and the promotion of long run growth of the economy.

Fasanya, Onakoya, and Agboluaje (2013) observed that despite efforts made towards achieving the desired macroeconomics objectives through monetary policy, the results have not been sustained over time. This relatively high rate of unemployment, increased poverty rate, low standard of living, unacceptable rate of inflation are manifest evidence, especially in less developed economies. Altering the mon- 
etary policy in the opinion of Ireland (2008) has vital effects on aggregate demand, output and prices. He identified several transmission channels through which policy actions are manifested in the real economy. These include the interest rate channel, balance sheet channel, the bank lending channel and the exchange rate channel.

Several studies have reported conflicting relationship between the effect of monetary policies and the performance of the manufacturing sector. Different reasons have also been adduced. Adebiyi and Babatope (2004) and Rasheed (2010) suggest that the manufacturing sector growth level had been negatively affected due to high lending rate interest which, is in turn responsible for high cost of production. The reason adduced by Bakare-Aremu and Osobase (2014) for the declining performance of the sector are the low level of budget implementation by government and monetary policy summersault by the monetary authorities. The epileptic manufacturing sector contributions to national growth in the opinion was firmly laid by Okafor (2012) on the inconsistent monetary policies leading to the inflationary pressures. Indeed, inflation remains a major threat to the Nigerian industrial growth despite the various monetary regimes that have been adopted by the Central Bank of Nigeria. However there seem to be no correlation between the two variables.

The prevalence of these macroeconomic difficulties as mentioned above clearly showed that the issues of economic development especially in Nigeria might not have been effectively addressed by monetary policy. The essence of the study therefore, is the scrutiny of the possible impact of monetary policy on the sustainability of manufacturing firms in Nigeria.

The remaining part of the research is section two and three covering the review of literature and the estimation method respectively. In sections four, the results are presented whilst the conclusion and recommendation are reported in section five.

\section{LITERATURE REVIEW}

This section focuses on the review of both theoretical and empirical literature.

\subsection{Theoretical Review}

The classical theory postulate that in the short run, the monetary transmission mechanism of monetary policy is neutral in influencing employment, income, real aggregate demand and output. The changes in the supply of money however, affect the real sector magnitudes in the transition period. The nexus between prices levels and money supply is illustrated in Figure 1. 
Figure 1.: The Quantity of Money, Price Levels and National Income

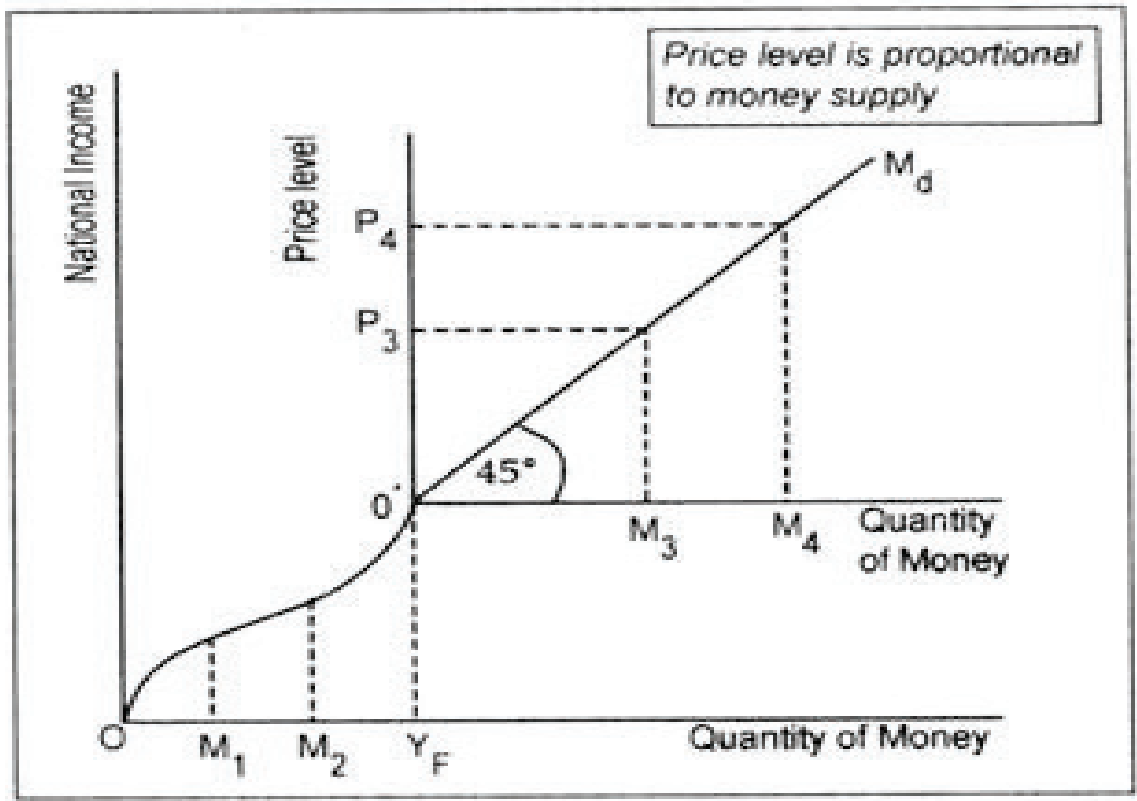

Source: www.economicsdiscussion.net/Money/Quantity Theory of Money/Theories

The relationship between national output and the supply of money is depicted at the origin $(\mathrm{O})$ which is below the level of full employment $\left(\mathrm{Y}_{\mathrm{F}}\right)$. At the level of full employment, the connection between price level and money supply is depicted at origin $\left(\mathrm{O}^{\prime}\right)$. Prior to the achievement of full employment level $\left(\mathrm{Y}_{\mathrm{F}}\right)$, a rise in the supply of money (from $\mathrm{OM}_{1}$ to $\mathrm{OM}_{2}$ and to $\mathrm{OY}_{\mathrm{F}}$ ) results in a rapid increase in the national output, which is in excess of the increases in the price level. With efficient utilization of national resources, and increases in investment arising from increased supply of money, the national output can be increased. Given the limitation of output expansion due to the attainment of full employment, a rise in the supply of money from say $M_{3}$ to $M_{4}$ will propel the price level to move up rise from $P_{3}$ to $P_{4}$. For the sustenance of stable price levels, the supply money should rise in proportion to growth in output.

The disputation of the monetarists (Fisher, Pigou and Marshall) is that the velocity of money (V) is exogenously determined and is totally independently of the supply of money (M) in the long- run. Consequently, any variation in money supply $(\mathrm{M})$ does not affect velocity $(\mathrm{V})$ but brings an equivalent variation in expenditure (MV). This is because of the relatively fixed output in the long run. Indeed, variations in the price level (P) is shaped by the fluctuations in the stock of money (Friedman, 1968). Consequently, monetary policy could be a powerful tool for controlling national output / aggregate demand (PQ). 
The theory of portfolio balance postulates that individuals hold diversified assets: physical assets, bonds, bills, shares commercial papers etc. A portfolio disturbance occurs when the supply of money supply is increased, resulting in idle money in the hand of the people. The extra funds are spent in buying liquid assets and near money, which increases their market price. This portfolios restructuring continues equilibrium is achieved. This of course has similar implications for the manufacturing sector, a sub-set of the national economy.

The Keynesians on the other hand postulates that except when at the approach of full employment, the aggregate supply is relatively elastic, in which case $Q$ is variable. Therefore, a tight monetary policy will most likely cause a reduction in output and the price level to the extent that it does upset aggregate demand. This is especially so where trade unions and monopolistic firms resist cuts wage and prices. The consequential impact of this is the possibility of a prolonged recession where the monetary policy successfully reduces aggregate demand.

A contrary position taken by the Keynesians is that no direct nexus exist between a variation in the supply of money and aggregate demand. The transmission mechanisms are affected indirectly through variations in interest rates and / or exchange rates. Indeed, with the economy at less than full employment equilibrium, the transmission is automatic. The mechanism is ignited by a change in the interest rate regime from the financial intermediation system to the real sector of the economy. This cuts off and de-emphasizes the direct role of money supply influence on the real sector because due to the liquidity preferences of the public, an increase in the supply of money reduces the general level of interest rate. This in turn stimulates investments. An expectation of returns marginal efficiency of investment and investors' confidence further enhance the employment of resources and output.

Under the balance of payments flow approach, the market demand and supply for foreign currency determines the price of the domestic currency (Copeland, 2000). The demand and supply for a currency are generated from the foreign direct and portfolio investments, trading activities in goods and services, and funds transfers (Feridun, Folawewo and Osinubi. 2005). The emphasis of the modern exchange rate model is on the role of the financial-asset markets as monetary transmission mechanism. Unlike the traditional opinion that adjusting the rate of exchange equilibrates the international trade in commodities, seeking equilibrium of the financial assets is the main concern of the modern exchange rate model. The greater flexibility, fluctuation and variation of the prices of financial asset relative to commodities has led to a shift in emphasis from goods markets to financial asset markets. The consequence of this for the monetary authorities is germane particularly in the use of the exchange rate channel for managing the economy in general and the manufacturing sector in particular.

The monetary transmission as presented by the classical, Monetarist and Keynesian schools of thought demonstrates that the quantity of money in circulation goes a long way to determine the value, which people attach to it. This in part, de- 
termines the cost and prices of manufacturing operations and products respectively. The monetary theory of inflation in addition, suggests that money supply as a major determinant of output and prices bear strong similarity to the Fisher's theory in the strength of influence exerted by supply money on the economy.

\subsection{Empirical Review}

The literature records diverse impact of monetary regulations and stratagem on the different sectors of the economy. The year 2000 Hayo and Uhlenbrock's study measured the impact monetary policy German industrial outputs and report disparate consequences. Similar research by Dedola and Lippi (2000) using secondary data from five OECD also report dissimilar effects across the economic sectors. The study by Sahinöz and Coşar (2010) had the objective of investigating the influence of monetary policy shock on the output of the manufacturing industries in Turkey. The degree reduction in output is distributed unevenly across the sector. The rate of decline in the output of the manufacturing firms is greater at the onset of the introduction of the monetary policy. The decline bottoms-up by the end of the third quarters. The fiscal and monetary policy influence of on the Indonesian manufacturing sector was of interest to Oktaviani, Hakim, Siregar and Sahara (2010) who found powerful minimizing impact monetary policy on external and internal shocks.

The transmission mechanism by which the monetary policy translates into action has engaged the attention of several studies. Examples are the credit channel method by Kahn (2010), the Classical school expounded upon by Majumder (2007), and the Keynesian approach by Barro (1997). The specific study in Kenya by Olweny and Chiluwe (2012) traced the transmission mechanism through which the effect of formulated monetary policy manifest in the economy. The results are conflicting in the short run and long run.

Charles- Anyaogu (2012) investigated the performance of monetary policy on manufacturing sector in Nigeria. The findings signpost the fact that the manufacturing index performance positively money influences supply. On the other hand, negative effect on the output of manufacturing sector is manifested in the lending rate of the company, the rates of income tax, inflation and exchange. A more complex study by Odior (2013) in Nigeria deployed the VECM method and reveal long-term positive connection between monetary policy and manufacturing output. The thirtysix-year (1973-2009) Nigerian study by Obamuyi, Edun, and Kayode (2011) also applied the VECM method. They came to similar conclusion that reduced bank interest leads to increased capacity utilization of the manufacturing. Bakare-Aremu and Osobase conducted a similar study in 2014 using both monetary and fiscal policies and reported that both variables influence the growth and development of Nigerian industrial sector. Indeed, Akano (2016) recorded several policy summersaults in the country over the years, which led to the parlous impact on the economy. 
The research by Sangosanya (2011) which, was predicated on the Gibrat's law of proportionate outcome deployed the panel regression analysis technique. The study came to the same conclusion by Bakare (2011) who in own case reported the existence of an optimum debt-equity mix for firms that monetary policy influences the operations of the manufacturing firms. Similar study in Republic of Sudan by Abdulrahman (2010) reports that the deployment of monetary policy had little bearing on manufacturing activity between 1990 and 2004. Epstein and Heintz (2006) came to analogous conclusion in Ghana. Alam and Waheed (2006) who took the matter further in Pakistan using quarterly data from 1973:1 to 2003:4. The results of Ordinary least Squares suggest that significant changes in the real sector were transmitted by the shocks arising from the monetary regulations.

The review of theoretical and empirical literature has opened the avenue for the exploration of the possible influence of monetary policy on the sustainability of the manufacturing sector.

\section{METHODOLOGY}

\subsection{Data Source and Description}

Secondary data were obtained from the World Bank Development Indicators (2016), Central Bank of Nigeria Statistical Bulletin (2005 and 2015) covering 1981 through 2015. The period is sufficiently large enough for a comprehensive review of the impact of monetary policy on the performance of the manufacturing sector in Nigeria based on the scope of the study. The proxy for manufacturing sector output (MOP) is the sectorial contribution of manufacturing to GDP. Other data for analysis include external reserves (EXTRE), exchange rate (EXR), Broad money supply $\left(M S_{2}\right)$, inflation rate (INF) and Interest Rate (INT). The next presentation is on the specification of the model.

\subsection{Model Specification}

Altering the monetary policy in the opinion of Ireland (2008) has vital effects on aggregate demand, output and prices. He identified several transmission channels through policy actions are manifested in the real economy. These include the interest rate channel, balance sheet channel, the bank-lending channel and the exchange rate channel. This study adopts the Ireland model and base the operationalization and analytical procedure on the assumption of Keynesian Investment-Savings - Liquidity-Money function. The following relationship model is derived:

$$
\mathrm{MOP}=\mathrm{f}\left(\mathrm{MS}_{2}, \mathrm{INF}, \mathrm{INT}, \text { EXRE, EXRATE }\right)
$$

As a result of the large magnitude of the value of some of the idependent variables however, the log-log mode is applied (except for in- 
flation and interest rates). Equation (1) thus transmutes into: $L N M O P=\alpha_{0}+a_{1} L N M S_{t}+b_{2} I N F_{t}-c_{3} I N T_{t}-d_{4} L N E X R E_{t}-e_{5} L N E X R A T E_{t}+\varepsilon_{t}$

Where:

$M O P$ = manufacturing sector output (manufacturing Output to GDP)

EXTRE $=$ external reserves,

$E X R=$ exchange rate,

$M S_{2}=$ Broad money supply,

INF = inflation rate,

$I N T=$ Interest Rate

$\mathcal{E}_{t}=$ Stochastic term (error term); and

$\mathrm{a}_{\circ}>0, a_{1}>0, b_{2}>0, c_{3}<0, d_{4}<0, e_{5}<0$, apiori expectations of parameters.

\subsection{Model Estimation Procedure}

The study employs three-step procedural steps. The first step is the use of descriptive statistics in order to understand the nature of the data. The next step is the determination of the stability of the variables. The Augmented Dickey-fuller (ADF) unit root test was deployed. In the second step, the optimal lag length is selected before conducting the Johansen co-integration long-run test. The Vector Error Correction Model (VECM), a test for short run relationships or dynamics between variables is also conducted as specified as in equation (3):

$$
\begin{aligned}
& \Delta \text { LnMOP }_{t-1}=a_{0}+\sum_{i=1}^{p} b_{t} \Delta \operatorname{lnMS}_{t-1}+\sum_{i=1}^{p} C_{t} \Delta I N F_{t-1}-\sum_{i=1}^{p} d_{t} \Delta I N T_{t-1}- \\
& \sum_{i=1}^{p} e_{t} \Delta \operatorname{LnEXTRE}_{t-1}+\sum_{i=1}^{p} f_{t} \Delta L n E X R A T E_{t-1}+\operatorname{piECT} T_{t-1}+\epsilon_{t}
\end{aligned}
$$

Where $\Delta$ is the first difference operator, $\alpha_{t}$ and $b_{t}, c_{t}, d_{t} e_{t,}$ and $f_{t}$ are the coefficients estimated from equation (2). The VECM mechanism will indeed tell how much of deviation from the long run is being corrected.

In order to confirm the robustness and validity of regression model, some post estimation tests were conducted. These are the autocorrelation, and Heteroscedasticity tests. E-views version 8.0 software was utilized to compute these tests. Having described the estimation procedure, the next discussion is on the preliminary analysis of the data.

\section{FINDINGS AND DISCUSSIONS}

\subsection{Preliminary Analyses}

The preliminary analyses are in two parts: descriptive statistics and stationarity test 


\subsubsection{Descriptive Statistics}

The summary of the descriptive statistics of the variables are, presented in Table 1. Table 1.: Descriptive Statistics of the Variables

\begin{tabular}{|l|r|r|r|r|r|r|}
\hline \multicolumn{1}{|c|}{ Statistics } & LNEXRATE & \multicolumn{1}{c|}{ INF } & INT & LNEXTRE & \multicolumn{1}{c|}{ LNMOP } & \multicolumn{1}{c|}{ LNMS2 } \\
\hline Mean & 3.23 & 19.72 & 17.81 & 11.06 & 25.56 & 27.04 \\
Median & 3.09 & 12.22 & 17.80 & 11.06 & 25.69 & 26.99 \\
Maximum & 5.26 & 72.84 & 31.65 & 12.58 & 29.83 & 30.55 \\
Minimum & -0.48 & 5.38 & 8.92 & 8.61 & 22.27 & 23.45 \\
Std. Dev. & 1.94 & 17.94 & 5.04 & 1.10 & 2.39 & 2.45 \\
Skewness & -0.71 & 1.63 & 0.18 & -0.48 & 0.25 & -0.02 \\
Kurtosis & 2.15 & 4.37 & 3.43 & 2.25 & 2.037 & 1.63 \\
Jarque-Bera & 4.03 & 18.17 & 0.44 & 2.15 & 1.73 & 2.73 \\
Probability & 0.13 & 0.000113 & 0.80 & 0.34 & 0.42 & 0.26 \\
Sum & 112.88 & 690.01 & 623.18 & 387.14 & 894.62 & 946.32 \\
Sum Sq. Dev. & 128.12 & 10937.60 & 863.24 & 4.0 .91 & 194.23 & 203.18 \\
Observations & 35 & 35 & 35 & 35 & 35 & 35 \\
\hline
\end{tabular}

Source: Authors' computation using E-views 8.0 (2017)

As shown in Table 1., there exist a wide variation in within all the variables. The results based on the statistical distribution of the series shows that inflation, interest and the manufacturing sector output are skewed positively while others are negatively skewed. The values of exchange rate, external reserves and money supply are slightly platykurtic because of value kurtosis of less than 3 . The inflation and interest rates are leptokurtic. The goodness of fit test (Jacque-Bera) statistic is an indication of the normality of the series shows that all the variables are not normally distributed. A further test of stationarity is therefore required. This is reported in the next section.

\subsubsection{Stationarity Test Results}

The results of the Augmented Dickey Fuller (ADF) test is presented in Table 2.

Table 2.: Unit Root Test Results: Augmented Dickey Fuller Test

\begin{tabular}{|l|r|c|r|r|}
\hline \multicolumn{1}{|c|}{ Series } & \multicolumn{1}{|c|}{$\begin{array}{c}\text { \% Critical } \\
\text { Value }\end{array}$} & $\begin{array}{c}\text { ADFTest at } \\
\text { first difference } \\
\text { (Prob.) }\end{array}$ & $\begin{array}{c}\text { Equation } \\
\text { Specification }\end{array}$ & $\begin{array}{c}\text { Order of } \\
\text { integration }\end{array}$ \\
\hline INF & -2.96 & $-5.35(0.00)$ & Intercept & I(l) \\
INT & -2.96 & $-5.05(0.00)$ & Intercept & I(l) \\
LNEXRATE & -2.96 & $-4.96(0.00)$ & Intercept & I(l) \\
LNEXTRE & -2.96 & $-6.86(0.00)$ & Intercept & I(1) \\
\hline
\end{tabular}




\begin{tabular}{|l|c|c|r|r|}
\hline \multicolumn{1}{|c|}{ Series } & $\begin{array}{c}\text { 5\% Critical } \\
\text { Value }\end{array}$ & $\begin{array}{c}\text { ADFTest at } \\
\text { first difference } \\
\text { (Prob.) }\end{array}$ & $\begin{array}{c}\text { Equation } \\
\text { Specification }\end{array}$ & $\begin{array}{c}\text { Order of } \\
\text { integration }\end{array}$ \\
\hline LNMOP & -2.96 & $-5.45(0.00)$ & Intercept & $\mathrm{I}(1)$ \\
LNMS2 & -2.96 & $-3.27(0.00)$ & Intercept & $\mathrm{I}(1)$ \\
\hline
\end{tabular}

Source: Authors computation using E-Views 8.0 (2017)

Given that all the variables are integrated in order of at unity, the appropriate estimation technique to be deployed is the Johansen Co-Integration test. The selection of an optimal lag length will have to be conducted. This done in the next section.

\subsection{Estimation Results}

\subsubsection{Optimal Lag Length Selection}

The result of the lag length, which explains the effect of the outcome of previous period on the current one, is presented in Table 3.

Table 3.: Optimal Lag Length Selection Criteria

\begin{tabular}{|l|r|r|r|r|r|r|}
\hline Laglength & \multicolumn{1}{c|}{ LogL } & \multicolumn{1}{c|}{ LR } & \multicolumn{1}{c|}{ FPE } & \multicolumn{1}{c|}{ AIC } & \multicolumn{1}{c|}{ SC } & \multicolumn{1}{c|}{ HQ } \\
\hline 0 & -231.59 & NA & 0.11 & 14.85 & $15.12^{*}$ & $14.94^{*}$ \\
1 & -190.74 & $63.83^{*}$ & 0.09 & 14.55 & 16.47 & 15.18 \\
2 & -148.61 & 50.03 & $0.08^{*}$ & $14.16^{*}$ & 17.74 & 15.35 \\
\hline
\end{tabular}

Source: Authors computation using E-views 8.o(2017)

* indicates lag order selected by the criterion

LR: sequential modified LR test statistic (each test at $5 \%$ level)

FPE: Final prediction error

AIC: Akaike information criterion

SC: Schwarz information criterion

HQ: -Hannan- Quinn information criterion

The test criteria (LR, FPE, AIC, SC and HQ) selected different lag lengths. The results of Schwarz information criteria and Hannan- Quinn information criterion depicting lag order length of (o) for the model is selected. This implies that the lagged values of the series are not correlated with the current values. The estimated long-run co-integration, and short run VECM are presented and discussed in the next section. 


\subsubsection{Johansen Co-Integration Test Result}

Table 4.: Result of Long Run Johansen Co-Integration Test Result

\begin{tabular}{|c|c|c|c|c|c|c|c|}
\hline \multicolumn{6}{|c|}{ Trace Statistic } & \multicolumn{2}{|c|}{ Max-Eigen Value } \\
\hline $\begin{array}{l}\text { No. of } \\
\text { CE(s) }\end{array}$ & Eigenvalue & $\begin{array}{r}\text { Trace } \\
\text { Statistic }\end{array}$ & $\begin{array}{r}0.05 \\
\text { Critical } \\
\text { Value }\end{array}$ & Prob. & $\begin{array}{r}\text { Max-Eigen } \\
\text { Value }\end{array}$ & $\begin{array}{r}0.05 \\
\text { Critical } \\
\text { Value }\end{array}$ & Prob.** \\
\hline None* & 0.83 & 135.30 & 95.75 & 0.00 & 55.42 & 40.08 & 0.00 \\
\hline At most 1 * & 0.67 & 79.88 & 69.82 & 0.01 & 34.05 & 33.88 & 0.05 \\
\hline At most 2 & $0.5^{1}$ & 45.83 & 47.86 & 0.08 & 22.31 & $27 \cdot 5^{8}$ & 0.21 \\
\hline At most 3 & 0.31 & $23.5^{3}$ & 29.80 & 0.09 & 11.42 & 21.13 & 0.61 \\
\hline At most 4 & 0.19 & 12.10 & $15.5^{\circ}$ & 0.05 & 6.34 & 14.27 & 0.57 \\
\hline At most $5^{*}$ & 0.17 & $5 \cdot 77$ & 3.84 & 0.02 & 5.77 & 3.84 & 0.02 \\
\hline
\end{tabular}

Source: Authors computation using E-views 8.0 (2017

The result of the Johansen co-integration test in Table 4. is divided into two namely the Eigenvalue and Trace statistic tests. The result shows that at most, five variables exhibited long run association with the dependent variable based on the satisfaction of the decision criteria (Trace Statistic and Max-Eigen Value being both greater than the $5 \%$ Critical Value) as provided for the selection of the alternative hypotheses.

The Vector Error Correction model test result in Table 5., for the short run association among the variables, reveals the absence of any short run association amongst the external reserves, inflation rate and the dependent variable - manufacturing output. A contrary case holds for interest rate, exchange rate and money supply.

Table 5.: Result of Short Run VECM Result

\begin{tabular}{|c|c|c|c|c|c|c|}
\hline $\begin{array}{l}\text { Error Cor- } \\
\text { rection: }\end{array}$ & D(LNMOP,2) & $\mathrm{D}(\mathrm{INF}, 2)$ & $\begin{array}{l}\text { D (INT, } \\
\text { 2) }\end{array}$ & $\begin{array}{l}\text { D(LNEX } \\
\text { RATE,2) }\end{array}$ & $\begin{array}{c}\mathrm{D}(\mathrm{LNEXT} \\
\mathrm{RE}, 2)\end{array}$ & $\mathrm{D}\left(\mathrm{LNMS}_{2,2}\right)$ \\
\hline \multirow[t]{2}{*}{ CointEq1 } & -0.17 & 5.05 & 4.29 & 0.44 & -0.10 & 0.12 \\
\hline & $(0.19)$ & $(6.73)$ & $(1.43)$ & $(0.16)$ & $(0.29)$ & $(0.05)$ \\
\hline T-stat (Cal) & {$[-0.95]$} & [0.75] & [2.99] & {$[2.78]$} & {$[-0.36]$} & {$[2.65]$} \\
\hline \multicolumn{7}{|c|}{ Regression Result } \\
\hline Variable & $\begin{array}{r}\text { Co-Efficient } \\
\text { (After } \\
\text { Normalization) }\end{array}$ & Standard Error & \multicolumn{4}{|c|}{ T-Statistic (2.05 at df 29 ). } \\
\hline LNMOP & 1.00 & & \multirow{2}{*}{\multicolumn{4}{|c|}{3.70}} \\
\hline $\mathrm{LNMS}_{2}$ & 1.81 & 0.49 & & & & \\
\hline INF & 0.07 & 0.01 & \multicolumn{4}{|c|}{8.66} \\
\hline INT & -0.01 & 0.04 & \multicolumn{4}{|c|}{-0.23} \\
\hline LNEXTRE & -1.05 & 0.22 & \multicolumn{4}{|c|}{-4.84} \\
\hline LNEXRATE & -0.18 & 0.34 & \multirow{2}{*}{\multicolumn{4}{|c|}{$-0.5^{2}$}} \\
\hline R-Squared & 0.60 & & & & & \\
\hline $\begin{array}{l}\text { Adjusted } \\
\text { R-Squared }\end{array}$ & $0.5^{6}$ & & & & & \\
\hline
\end{tabular}

Source: Authors computation using E-views 8.0 (2017) 
The estimated model is restated in equation (4) as:

$L N M O P=-0.17+1.81 L_{N M S_{2}}+0.07$ INF - 0.01 INT-1.05 LNEXTRE-0.18LNEXRATE (4)

The regression result indicates that broad money supply $\left(\mathrm{MS}_{2}\right)$ and inflation rate have positive and significant relationship with manufacturing output at 5 percent since the absolute calculated t statistics (3.70 and 8.66) are greater than tabulated t-statistics (2.05 at $\left.\mathrm{df}_{29}\right)$.

Anegative relationship however exists among interest rate, exchange rate on the one hand and manufacturing output on the other. Both independent variables were not statistically significant since absolute calculated t statistics (0.23 and 0.52$)$ are less than tabulated $\mathrm{t}$-statistics $\left(2.05\right.$ at $\left.\mathrm{df}_{29}\right)$. The external reserves is significantly but negatively related to manufacturing output.

The Adjusted R-squared of $56 \%$ indicates that only $56 \%$ of the variations in manufacturing output to GDP is explained by broad money supply $\left(\mathrm{MS}_{2}\right)$, inflation rate, interest rate, exchange rate and external reserves.

\subsection{Post-Estimation Tests}

It is still necessary to confirm the validity and robustness of the model. To achieve this, the study conducted the Breusch- Godfrey serial correlation LM test, Durbin Watson statistic test, Breusch-Pagan-Heteroscedasticity tests. The results are presented in the next sub-sections

\subsubsection{Breusch-Godfrey Serial Correlation Lm Test}

The result of the Breusch-Godfrey Serial Correlation Lm Test which essence is to check for possible serial relationship between the variables can be found in Table 6 .

Table 6.: Result of Breusch-Godfrey Serial Correlation LM Test

\begin{tabular}{|l|c|c|c|}
\hline F-statistic & $\mathbf{1 4 9 0 . 5 5}$ & Prob. F (2,25) & 0.00 \\
\hline Obs*R-squared & 33.71 & Prob. Chi-Square (2) & 0.00 \\
\hline
\end{tabular}

Source: Authors computation using E-views 8.० (2017)

The result shows the presence of serial correlation probability given that the chi-square value of 0.00 is lesser than the $5 \%$ level of significance. Next test is the Durbin Watson statistics, which is used to detect the presence of autocorrelation in the residuals.

\subsubsection{Durbin Watson statistics Tests}

This result of the test performed to determine the level of auto-correlation between the variables is presented in Table $\eta$. 
Table 7.: Durbin Watson Autocorrelation Test Results

\begin{tabular}{|l|c|c|c|}
\hline DW value (d) & D-UPPER $(\mathbf{d U}, \boldsymbol{\alpha}, \mathbf{)}$ & D-LOWER (dL, $\boldsymbol{\alpha}, \mathbf{)}$ & DECISION CRITERIA \\
\hline 1.02 & 1.88 & 1.10 & Reject auto-correlation \\
\hline
\end{tabular}

Source: Authors computation using E-views 8.o (2017)

The import of this test is to ascertain if the disturbance terms are correlated over time. The Durbin Watson statistics is very useful for the immediate past period. The result shows absence of auto-correlation result exists since $d$.

\subsubsection{Breusch-Pagan-Heteroscedasticity Tests}

One of the basic assumptions of OLS is the absence of heteroscedasticity as it can invalidate statistical tests of significance that assume that the modelling errors are uncorrelated and uniform. In order to test for heteroscedasticity, the study conducted the Breusch Pagan test to show how good and fit the model is. This result is presented in Table 8 .

Table 8.: Result of Breusch-Pagan-Godfrey Heteroscedasticity Test

\begin{tabular}{|l|r|r|r|}
\hline F-statistic & 2.35 & Prob. F (6,27) & 0.06 \\
Obs*R-squared & 11.65 & Prob. Chi-Square (6) & 0.07 \\
Scaled explained SS & 4.88 & Prob. Chi Square (6) & 0.56 \\
\hline
\end{tabular}

Source: Authors computation using E-views 8.o (2017)

After estimation, result shows that the Probability or P Value of the Obs* Rsquared is 0.06 which is greater than $5 \%$ level of significance therefore the acceptance of no presence of heteroscedasticity which is the null hypotheses.

As advised by Fox (1997) cited by Gujarati \& Porter, (2009), there is no need to be bothered about the presence of heteroscedasticity, unless the problem is severe. Because the validity model is not compromised.

\subsection{Discussion of Findings}

Monetary policy as described by Friedman (1959) is about the manipulation of the cost and availability of credits as to sway both monetary and other financial conditions. It is therefore appropriate to utilize the supply broad of money as a proxy for monetary policy. The result of this research confirms the positive and significant relationship between broad money supply, and manufacturing output. Indeed, an increase of about 1 percent in broad money supply would about double (1.8\%) rise in manufacturing output. This is in congruence with the findings of Olweny and Mambo Chiluwe (2012); and Charles-Anyaogu (2012); Bakare-Aremu and Osobase (2014) and Odior (2013) in the context of Nigeria. Indeed, Shiryani and Bayram (2013) reported that an increase in the 
supply of broad money raises the production output of the Malaysian manufacturing sector due to the increased availability of investment facilities.

On the contrary, divergent findings of Sahinöz, and Coşar (2010) concluded that the manufacturing sector responded to contractionary monetary policy shock with a reduction in absolute output. The result of this research is in congruence with the Keynesian monetarist school of thought which states that any discretionary variation in money supply positively and permanently sways real output by reducing the rate of interest. This is because the direct transmission mechanism of increases money supply and boosts aggregate demand. Thus, monetary policy could be a powerful tool for controlling national output / aggregate demand since in the findings of this research monetary policies are significant determinants of manufacturing industry growth in Nigeria.

This study finds that inflation affects manufacturing output positively and significantly. This negates the postulation of the quantity theory of money that an upsurge in the supply of money would result in inflation in the short-run, which is harmful in terms of the productivity. Indeed, based on the regression result, in the long- run, the inflationary influence would is neutralized by the adjustments in price levels considering the minuscule effect of $7 \%$ change in manufacturing output because of $100 \%$ change in inflation. This research supports the findings of Mbutor (2014), and Ihsan and Anjum (2013) in Nigeria and Pakistan respectively which, reveal that rise in broad money supply, leads to boost in manufacturing sectoral growth in addition to resulting in inflationary spiral., It is however contrary to the finding of Modebe and Ezeaku (2,016).

Interest rate exert negative but insignificant effect on the manufacturing output. This finding is inconsistent with the report of the study of Odior (2013) that an increase in interest rate inhibits the availability of funds at reasonable rates to the manufacturing sector. High cost of funds reduced the ability of the companies to maximize their capacity utilization, which between 2009 and 2017 was an average of about $56 \%$ percent. The maximum-recorded utilization was about $61 \%$ in 2015 Q1. The lowest was about 49\% 2016 Q3. This contrast poorly with the average of $99 \%$ in Japan and $77 \%$ in the United States of America during the same period (Trading Economics, 2017).

The impact of foreign exchange rate movement on the real economy is also negative and insignificant. The instability in the exchange rate had led to higher cost of manufacturing production due to importation of raw materials at exorbitant prices. The insignificance of foreign exchange variation is explained by the Marshall Lerner condition. This theory states that the devaluation of the nation's currency only becomes beneficial when the sum of the foreign elasticity of demand for exports and the demand elasticity for imports in the devaluing nation exceeds unity. Nigeria imports most of its critical machineries, spare parts, raw materials and other manufacturing inputs while exporting primary commodities, with exogenously determined prices. 
The result of this study shows that an increase of about 1 percent increase in external reserves led to about $1.05 \%$ reduction in manufacturing output. The conventional viewpoint perceives external reserves as a store of assets that is available for influencing the exchange rate of the domestic currency (IMF, 2004; Nda, 2006). The Nigerian foreign exchange reserves recorded an average value of 10 billion USD between 1960 and 2017. The wide fluctuation from a minimum level of 63.22 USD Million in June 1968 to a maximum level of 62 billion USD in September of 2008 (Trading Economics, 2017) did not appear to affect the manufacturing production output. The adversely slanted terms of trade could not provide credible explanations for the lack of nexus between the foreign reserves and the output of the manufacturing sector. This is because between year 2000 and 2017, Nigeria had an average index points of 98.94, which is less than par. In addition, the terms of trade also varied widely. The highest index of about 160 was recorded in March of 2010 and the lowest of 49.4 .8 recorded in April 2006 (Trading Economics, 2017). The reason to be ascribe is the pre-eminence of the oil and gas sector in the economy, which is deleterious to the manufacturing industry.

\section{CONCLUSION}

The empirical findings in this study is that monetary policy has a positive and statistical significant relationship with manufacturing output both in the short and long run and meets the apriori expectation. The study therefore recommends that the government avoid monetary policy summersaults, which has been the bane of many developing economies. 


\section{REFERENCES}

Abdulrahman, Badreldin Mohamed Ahmed. "The role of monetary policy on economic activity in Sudan: An empirical investigation, 1990-2004." Journal of Human Science 44 (2010)

Adebiyi, Michael Adebayo, and Babasanmi Babatope-Obasa. "Institutional framework, interest rate policy and the financing of the Nigerian manufacturing sub-sector." In African Development and Poverty Reduction: A Macro-Micro Linkage Forum, (2004): 13-15

Akano, O. (2016). Trade, Technological Innovation and Development. $5^{\text {th }}$ Inaugural lecture, Samuel Ajayi Crowther University, Oyo, Professor of Development Economics

Alam, Tasneem, and Muhammad Waheed. "Sectoral effects of monetary policy: Evidence from Pakistan." The Pakistan Development Review (2006): 1103-1115

Bakare-Aremu, T. A. \& Osobase, A. O., An empirical analysis of response of Nigerian industrial output to macro-economic adjustment policies. International Journal of Management Sciences and humanities, 2(9), (2014): 178-196

Charles-Anyaogu N. B., Investigating the performance of monetary policy on manufacturing sector in Nigeria. Arabian Journal of Business and Management Review (OMAN Section), 2(1), 2012.

Chigbu E. E \& Okonkwo O.N., Monetary policy and Nigeria's quest for import substitution industrialization. Journal of Economics and Sustainable Development, 5(23), (2014): 99-105

Dedola, Luca, and Francesco Lippi. "The monetary transmission mechanism: evidence from the industries of five OECD countries." European Economic Review 49, no. 6 (2005): 1543-1569

Epstein, Gerald, and James Heintz. "Monetary policy and financial sector reform for employment creation and poverty reduction in Ghana." (2006)

Fasanya, I.O., Onakoya, A.B \& Agboluaje, M.A., Does monetary policy influence economic growth in Nigeria? Asian Economic and Financial Review, 3(5), (2013):635-646

Friedman, M., The quantity theory of money Assessment. In Milton Friedman (Ed.). The Quantity Theory of Money, Chicago: The University of Chicago Press, 1968.

Friedman, Milton. "The demand for money: some theoretical and empirical results." Journal of Political economy 67, no. 4 (1959): $327^{-3} 5^{1}$

Hayo, Bernd, and Birgit Uhlenbrock. "Industry effects of monetary policy in Germany." In Regional aspects of monetary policy in Europe, Springer US, (2000):127-158

Ihsan, I., \& Anjum, S. (2013). Impact of money supply (M2) on GDP of Pakistan. Global Journal of Management and Business, 13(6). Available from https://globaljournals.org/GJMBR_Volume13/1Impact-of-Money-Supply.pdf

Durlauf, Steven N., and Lawrence Blume, eds. The new Palgrave dictionary of economics. Vol. 6. Basingstoke: Palgrave Macmillan, 2008.

IMF (2004). Guidelines for Foreign Exchange Reserve Management, IMF: Washington DC.

Kaldor, Nicholas. Causes of the slow rate of economic growth of the United Kingdom: an inaugural lecture. Cambridge University Press, 1966.

Kaldor, Nicholas. "Strategic factors in economic development." (1967).

Modebe, N. J., Ezeaku, H.C., Dynamics of inflation and manufacturing sector performance in Nigeria: Analysis of effect and causality. International Journal of Economics and Financial Issues, 6(4), (2016): 14,00-14,06 
Mbutor, Mbutor O. "Inflation in Nigeria: How much is the function of money?." Journal of economics and international finance 6, no. 1 (2014): 21

National Bureau of Statistics (2016). Nigerian gross domestic product report issue quarter one 2016, Abuja - Nigeria. May Retrieved from nigerianstat.gov.ng/download/398.

Nda, A. M. (2006). Effective reserves management in Nigeria: Issues, challenges, and prospect. Central Bank of Nigeria Bullion, 3॰ (3), July - September

Nwosa, Philip Ifeakachukwu, Ajibola Mary Agbeluyi, and Olufemi Muibi Saibu. "Causal relationships between financial development, foreign direct investment and economic growth the case of Nigeria." International Journal of Business Administration 2, no. 4, (2011): 93-102

Obamuyi, Tomola Marshal, Adebisi T. Edun, and Olawale Femi Kayode. "Bank lending, economic growth and the performance of the manufacturing sector in Nigeria." European Scientific Journal, ESJ 8, no. 3 (2012):19-36

Odior, Ernest Simeon. "Macroeconomic variables and the productivity of the manufacturing sector in Nigeria: A static analysis approach." Journal of Emerging Issues in Economics, Finance and Banking 1, no. 5 (2013): $362-380$

Oktaviani R., Hakim D.B., Siregar H., Sahara, The impact of fiscal policy on Indonesian macroeconomic performance, agricultural sector and poverty incidences (ADynamic Computable General Equilibrium Analysis), Department of Socio-Economics Sciences Faculty of Agriculture, Bogor Agricultural University, 2010.

Olweny, Tobias, and Mambo Chiluwe. "The effect of monetary policy on private sector investment in Kenya." Journal of Applied Finance and Banking 2, no. 2 (2012): 239-287

Onakoya, A.B., The Kaldor-Verdoorn's law on manufacturing: Test of the Nigerian experience. Redeemer's University Journal of Management and Social Sciences, 3(1), (2015):37-49

Rasheed, O. A., Productivity in the Nigerian manufacturing sub-sector. European Journal of Economics, Finance and Administrative Sciences, 6(8), (2010): 1450-2275

Sahinöz, S. \& Coşar, E.E. (2010) Understanding sectoral growth cycles and the impact of monetary policy in the Turkish manufacturing industry. Central Bank of the Republic of Turkey, Working Paper No. 3. Retrieved from www.tcmb.gov.tr/wps/wcm/connect/dıdgfo34--5c31-4c8o.../WP1o13.pdf?

Sangosanya, A. O., Firm's growth dynamics in Nigeria's manufacturing industry: A panel analysis. Journal of Applied Econometric Review, 1(1), (2011): 2-15

Trading Economics (2017) Nigeria's capacity utilization 2009-2017. Retrieved from https:// tradingeconomics.com/nigeria/capacity-utilization 